\title{
Increased DNA methylation levels of the insulin-like growth factor binding protein 1 gene are associated with type 2 diabetes in Swedish men
}

Tianwei Gu ${ }^{1 *}$, Harvest F Gu', Agneta Hilding ${ }^{1}$, Louise K Sjöholm², Claes-Göran Östenson' ${ }^{1}$, Tomas J Ekström² and Kerstin Brismar ${ }^{1}$

\begin{abstract}
Background: Prospective studies have shown that low levels of circulating insulin-like growth factor binding protein-1 (IGFBP-1) are associated with the risk of type 2 diabetes. In the present study, we investigated DNA methylation in the IGFBPI gene to evaluate its changes in relation to serum IGFBP-1 levels in type 2 diabetes.

Results: A total of 406 Swedish men, including age-matched normal glucose tolerance subjects and type 2 diabetes patients either newly diagnosed or undergoing treatment, were selected from the Stockholm Diabetes Prevention Program. IGFBP1 methylation levels in genomic DNA extracted from peripheral blood were analysed by bisulfite pyrosequencing. Serum IGFBP-1 levels were measured by radio-immunoassay. We found that IGFBPI DNA methylation levels were higher in both newly diagnosed and treated type 2 diabetes patients with a mean diabetes duration of 3 years compared with subjects with normal glucose tolerance (19.8\% and $20.2 \%$ vs. $16.9 \%$, $P<0.001$ for both). Serum levels of IGFBP- 1 in newly diagnosed and in treated type 2 diabetes patients were lower compared with healthy individuals $(18 \mu \mathrm{g} / \mathrm{l}$ both vs. $24 \mu \mathrm{g} / \mathrm{l}, P=0.011, P<0.001)$. IGFBP1 methylation levels but not serum IGFBP-1 levels in type 2 diabetes patients were independent of body mass index. Newly diagnosed patients with a family history of diabetes (FHD) had higher IGFBP1 methylation levels than those without FHD (20.3\% vs. $18.6 \%, P=0.017)$.

Conclusions: This study provides the first evidence that changes in DNA methylation of the IGFBPI gene are associated with type 2 diabetes in Swedish men and suggests that increased IGFBP1 DNA methylation and decreased IGFBP-1 serum levels are features of type 2 diabetes with a short duration.
\end{abstract}

Keywords: IGFBP-1, DNA methylation, type 2 diabetes

\section{Background}

Type 2 diabetes mellitus is a complex metabolic disorder influenced by genetic and environmental factors. In recent years, genome-wide association studies (GWAS) have identified a number of confirmed genetic susceptibility variants for type 2 diabetes. However, GWAS findings can only explain approximately $10 \%$ of the overall heritable risk of type 2 diabetes, which challenges our expectations

\footnotetext{
* Correspondence: tianwei.gu@ki.se

${ }^{1}$ Rolf Luft Research Center for Diabetes and Endocrinology, Department of Molecular Medicine and Surgery, Karolinska Institute, Department of Endocrinology, Karolinska University Hospital, Stockholm SE-17176, Sweden Full list of author information is available at the end of the article
}

for translating genetic information into clinical practice [1-3]. One of the reasons for the missing information on heritability could be that epigenetic factors are involved in the complex interplay between genes and environment. Knowledge of the epigenetic factors associated with type 2 diabetes is still limited. Therefore, epigenetic studies may provide further information to give a better understanding of the pathogenesis of type 2 diabetes [4-6].

The circulating insulin-like growth factor binding protein-1 (IGFBP-1), produced in the liver, has an inhibitory effect on the action of insulin-like growth factors and is mainly regulated by portal insulin $[7,8]$. Clinical

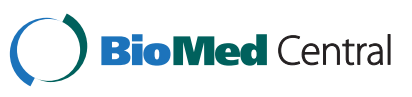


investigations have demonstrated that a low circulating level of IGFBP-1 is associated with insulin resistance, type 2 diabetes and the metabolic syndrome [9-11]. We have previously analysed IGFBP-1 serum levels in Swedish middle-aged and elderly twins and found that environmental influences predominate for IGFBP-1 levels [12]. We have also demonstrated that a low serum level of IGFBP-1 predicts the development of type 2 diabetes in middle-aged Swedish men and women $[9,13,14]$.

DNA methylation variation is hypothesized to alter individual susceptibility to type 2 diabetes [4]. DNA methylation levels are commonly analysed at clusters of $\mathrm{CpG}$ methylation sites in the genes and used to indicate epigenetic effects [15]. However, there are no reports from epigenetic studies of IGFBP1 in type 2 diabetes. It is unknown whether DNA methylation patterns of the IGFBP1 gene are associated with type 2 diabetes. In this study, we investigated DNA methylation levels of the IGFBP1 gene in Swedish men, including subjects with normal glucose tolerance or type 2 diabetes and analysed serum IGFBP-1 levels. Our study demonstrates that increased IGFBP1 methylation levels and reduced protein levels are associated with type 2 diabetes.

\section{Results}

\section{Association of IGFBP1 DNA methylation and IGFBP-1}

\section{serum levels with type 2 diabetes}

We conducted genomic DNA methylation analyses of six CpG sites in the human IGFBP1 gene. The IGFBP1 DNA methylation levels at each of the six CpG sites were significantly higher in both newly diagnosed type 2 diabetes patients (P1 24.3\%, P2 17.5\%, P3 15.0\%, P4 16.4\%, P5 21.3\% and P6 24.7\%) and treated patients (P1 24.6\%, P2 18.2\%, P3 15.8\%, P4 16.2\%, P5 21.6\% and P6 $24.7 \%)$ compared with those in non-diabetic subjects (P1 17.7\%, P2 15.6\%, P3 12.7\%, P4 13.\%, P5 19.5\% and P6 22.\%) $(P<0.001$ for all comparisons vs. nondiabetic controls) (Figure 1A). Combining all six CpG sites together, the mean values of IGFBP1 DNA methylation levels were significantly increased in both newly diagnosed and treated patients in comparison with non-diabetic subjects $(19.8 \%, 18.9 \%$ and $16.9 \%, P<$ 0.001 for both type 2 diabetes groups vs. controls) (Figure 1B). However, there were no differences in DNA methylation levels at any CpG site of the IGFBP1 gene between newly diagnosed patients and the patients on treatments. Further analyses were performed according to the different treatments given to the treated type 2 diabetes patients. IGFBP1 DNA methylation levels were similar in the treatment groups (20.7\% in patients on physical exercise and diet control, $19.4 \%$ in patients on oral anti-diabetic drugs (OADs), 20.4\% in patients on insulin treatment and $19.4 \%$ in patients on OADs + insulin).

We further analysed fasting serum IGFBP-1 levels and found that newly diagnosed and treated patients with type 2 diabetes had similar fasting serum IGFBP-1 levels $(18 \mu \mathrm{g} / \mathrm{l}$ in both groups), which were significantly lower than those in non-diabetic control subjects $(24 \mu \mathrm{g} / \mathrm{l}$, $P=0.011$ and $P<0.001$, respectively) (Figure $1 \mathrm{C}$ ).

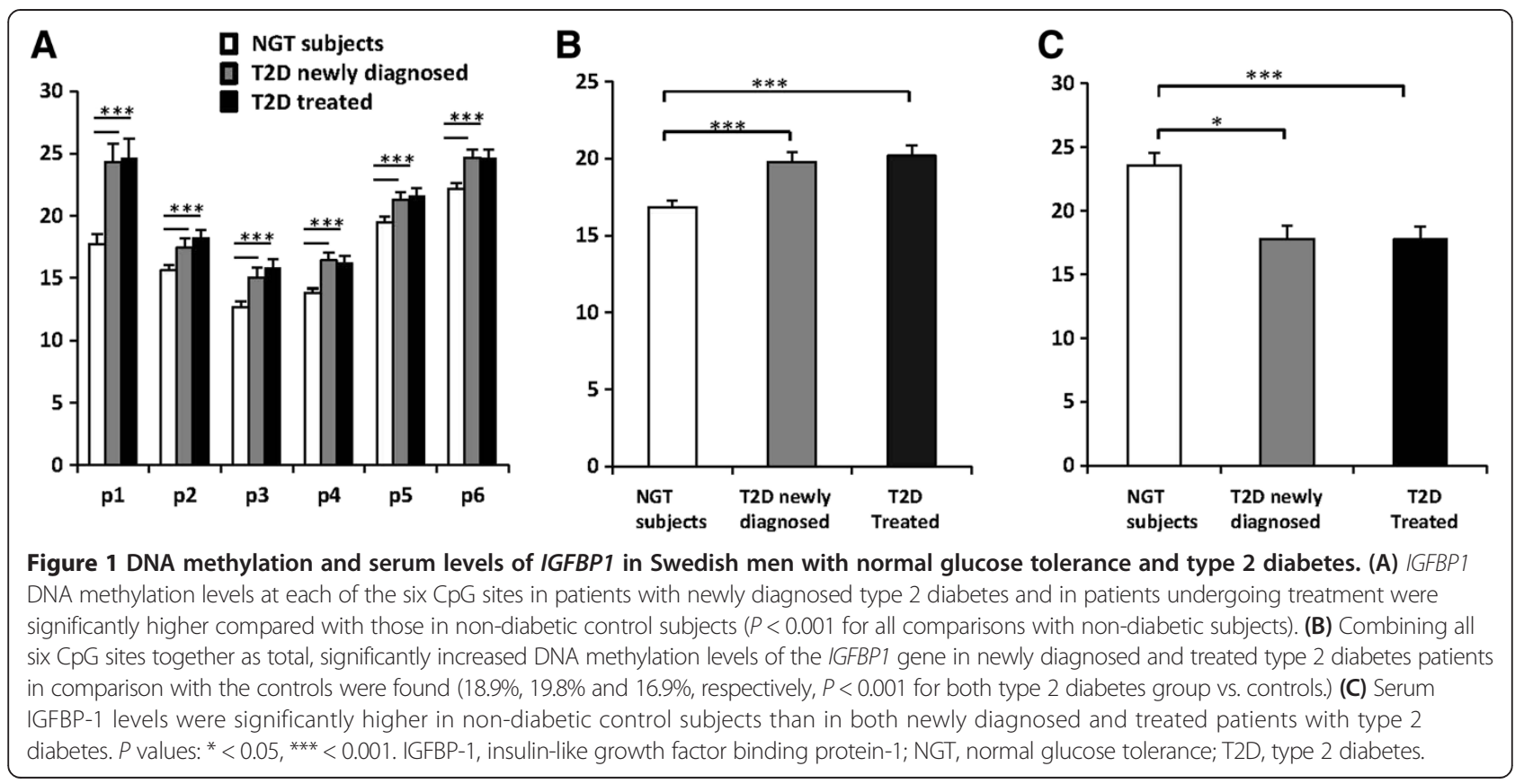




\section{Association of IGFBP1 DNA methylation and IGFBP-1 serum levels with family history of diabetes}

To understand whether IGFBP1 DNA methylation and serum IGFBP-1 levels are related to a family history of diabetes (FHD), we carried out comparison analyses between subjects with and without FHD. The data showed that non-diabetic control subjects with FHD had similar IGFBP1 DNA methylation levels (16.9\% and 17.0\%) but lower serum protein levels compared with those without FHD (19 vs. $25 \mu \mathrm{g} / \mathrm{L}, P=0.018)$ (Figure $2 \mathrm{~A}$ and $2 \mathrm{~B}$ ). Newly diagnosed type 2 diabetes patients with FHD had significantly increased IGFBP1 DNA methylation levels compared with the patients without FHD (20.3\% vs. $18.6 \%, P=0.017$ ) (Figure 2A). Although the geometric mean values of IGFBP-1 serum levels in newly diagnosed type 2 diabetes patients with FHD appeared lower compared with the patients without FHD, no significant difference was detected. Moreover, newly diagnosed patients with FHD had higher glucose $(8.1$ vs. $6.5 \mathrm{mmol} / \mathrm{l}$, $P=0.007)$ and higher insulin levels (179.1 vs. 138.3 pmol/l, $P=0.021)$ compared to patients without FHD (Figure 2B). There were no differences in the levels of IGFBP1 DNA methylation, serum IGFBP-1, glucose or insulin between treated type 2 diabetes patients with and without FHD.

\section{Association of IGFBP1 DNA methylation and IGFBP-1}

serum levels with body weight

To further investigate whether changes of IGFBP1 DNA methylation levels were related to body weight in type 2 diabetes, we conducted analyses according to body mass index (BMI). Subjects were divided into subgroups based on a BMI cut-off of $25 \mathrm{~kg} / \mathrm{m}^{2}$. There were no differences in the IGFBP1 DNA methylation levels between lean $\left(\mathrm{BMI}<25 \mathrm{~kg} / \mathrm{m}^{2}\right)$ and overweight/obese $\left(\mathrm{BMI} \geq 25 \mathrm{~kg} / \mathrm{m}^{2}\right)$ subjects in any of the three groups (Figure 3A). However, compared with overweight/obese subjects, lean individuals in the control group and newly diagnosed patients had significantly higher serum IGFBP-1 levels ( 29 vs. $22 \mu \mathrm{g} / \mathrm{l}, P=$ 0.022 ; 29 vs. $16 \mu \mathrm{g} / \mathrm{l}, P=0.011)$ and lower insulin levels ( 86.6 vs. $100.6 \mathrm{pmol} / \mathrm{l}, P=0.011 ; 98.9$ vs. $181.5 \mathrm{pmol} / \mathrm{l}, P<$ 0.001) (Figure 3B). No differences were found in fasting glucose levels between lean and overweight/obese subjects within any group.

We also conducted similar analyses for waist circumference with a cut-off at $94 \mathrm{~cm}$. Data showed that there

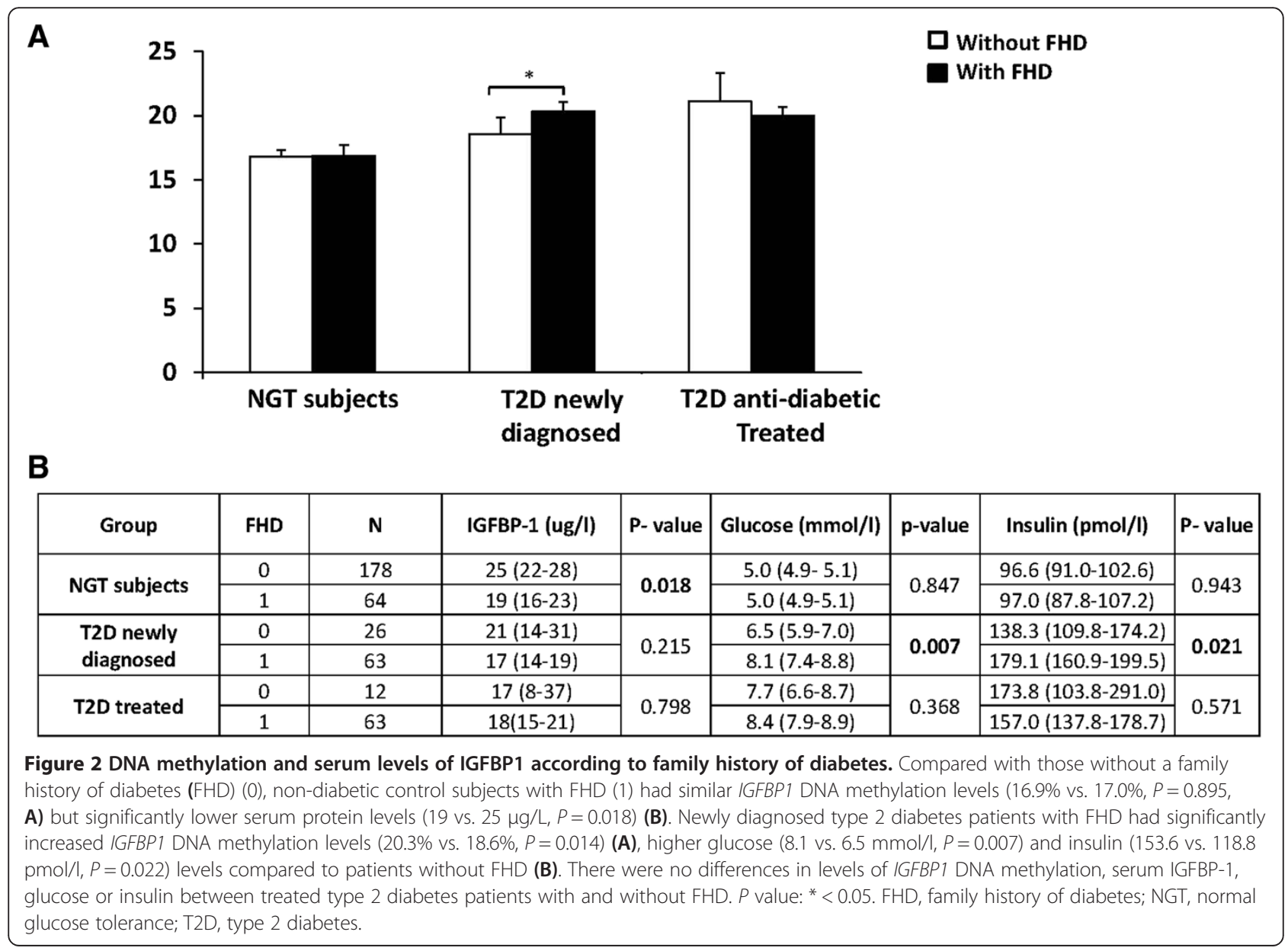




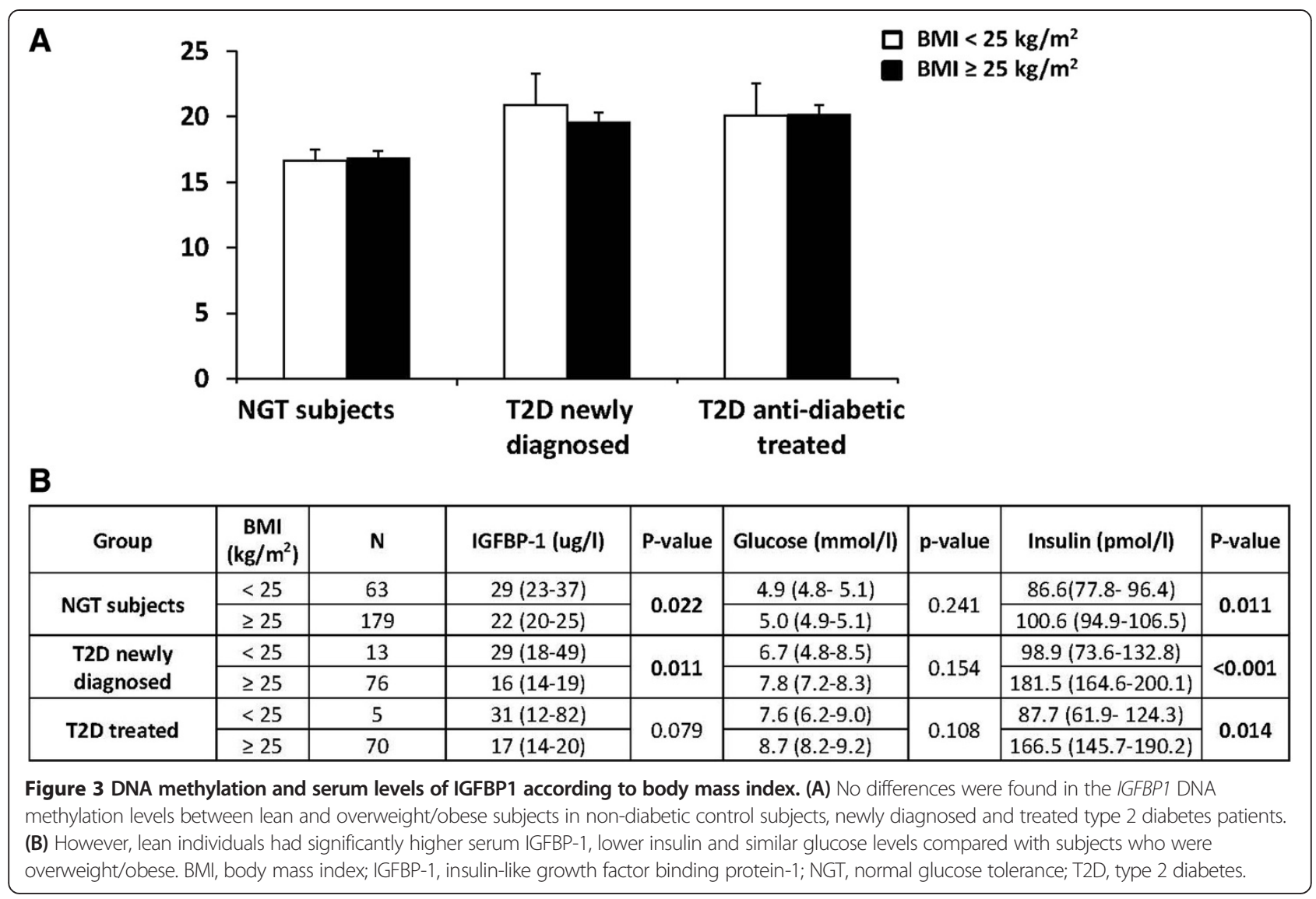

was no significant difference in IGFBP1 DNA methylation levels between subjects with waists $<94 \mathrm{~cm}$ and $\geq 94 \mathrm{~cm}$ within any group: non-diabetic control subjects (16.6\% vs. $17.1 \%, P=0.307)$, newly diagnosed $(19.7 \%$ vs. $20.2 \%, P=$ $0.551)$ and treated type 2 diabetes patients $(20.3 \%$ vs. $19.8 \%, P=0.607)$.

\section{Correlation between IGFBP1 DNA methylation levels and IGFBP-1 serum levels}

We analysed the correlation between IGFBP1 DNA methylation levels and IGFBP-1 serum levels. A borderline significant correlation between IGFBP1 DNA methylation levels and IGFBP-1 serum levels was found in non-diabetic subjects $(r=0.186, P=0.050)$, but not in newly diagnosed type 2 diabetes patients $(P=0.770)$ or patients undergoing treatment $(P=0.230)$.

\section{Discussion}

We conducted an epigenetic study of the human IGFBP1 gene in Swedish men with and without type 2 diabetes in parallel with analyses of fasting IGFBP-1 protein levels in serum. Our results demonstrated that compared with nondiabetic controls, DNA methylation levels of the IGFBP1 gene were higher in all type 2 diabetes patients, while IGFBP-1 serum levels were lower. Newly diagnosed type 2 diabetes patients with FHD had higher DNA methylation levels compared with those without FHD. Furthermore, IGFBP1 DNA methylation levels were found to be independent of BMI or waist circumference, while IGFBP-1 serum levels were inversely related to BMI.

It has been shown that DNA methylation is influenced by age, gender, genetic background, lifestyle and body weight [16-18]. To avoid the influence of age and gender, for our study we selected age-matched Swedish men including non-diabetic subjects, newly diagnosed type 2 diabetes patients not taking medication and patients undergoing treatment, from the Stockholm Diabetes Prevention Program (SDPP) cohort. There is a CpG island in the regions of the promoter and 5'-UTR of the IGFBP1 gene. By using wellselected and characterized subjects, we analysed six CpG sites in 5'-UTR, which may represent the methylation levels of IGFBP1. A previous study has demonstrated that high CpG density region at 5'-UTR recruits a methy-CpG binding protein to the promoter and represses gene transcription [19]. We found increased DNA methylation in all type 2 diabetes patients, who also had decreased circulating levels of IGFBP-1. However, we were not able to establish the causal relationship between IGFBP1 DNA methylation alteration and the development of type 2 diabetes from the current cross-sectional study. We further compared the 
IGFBP1 DNA methylation levels among subgroups of patients on different treatments, including diet, OAD, insulin and insulin plus OAD. There were no significant differences between the subgroups, suggesting no effect of diabetes treatment on IGFBP1 methylation levels. This could be due to the limited duration of type 2 diabetes in these patients (mean 3 years) and also that the numbers of individuals in the subgroups were relatively small.

In this study, we measured the fasting morning levels of IGFBP-1, which reflects IGFBP-1 secretion over the previous 24 hours and overall endogenous and exogenous insulin effect during the previous 24 hours [20]. Low serum IGFBP-1 levels are associated with hyperinsulinemia and subsequently with overweight or obesity $[13,14]$. We thus stratified the subjects according to BMI and waist circumference. The were no differences in the IGFBP1 DNA methylation levels for any of the three groups, suggesting that the variation of IGFBP1 DNA methylation was due to the type 2 diabetes, rather than being overweight or obese. In addition, we analysed the IGFBP1 DNA methylation levels according to lifestyle factors including smoking status, physical activity levels and alcohol consumption. We found no significant differences within any group (data not shown).

When evaluating IGFBP1 DNA methylation levels in type 2 diabetes patients according to FHD, we found that newly diagnosed patients with FHD not only had higher fasting glucose and insulin levels but also increased IGFBP1 DNA methylation. This implies that there could be a trans-generation effect in patients with FHD. Furthermore, newly diagnosed patients with FHD had hyperinsulinemia and impaired glucose tolerance for a longer time before diagnosis compared with those without FHD [21].

There are limitations of the present study. First, there is the lack of human liver tissue samples for methylation analysis. We do not know whether IGFBP1 DNA methylation levels in peripheral blood cells do reflect its methylation levels in the liver. However, we observed a weak correlation between IGFBP1 DNA methylation levels in peripheral blood cells and circulating IGFBP-1 serum levels in non-diabetic subjects. Type 2 diabetes is a complex disease. The correlation between DNA methylation and serum protein levels is influenced by multiple factors, which may explain the lack of correlation between IGFBP1 DNA methylation and serum IGFBP-1 levels in type 2 diabetes patients. Second, our patients had diabetes for only a short time. Therefore, the effects of diabetes treatment on DNA methylation might be too trivial to detect. Analyses of liver-tissue-specific DNA methylation levels, gene transcription in liver cell lines after RNA interference at CpG sites and using patients with longstanding diabetes are being considered for further investigation.

\section{Conclusions}

In this study, we provide the first evidence that DNA methylation changes of the IGFBP1 gene are associated with type 2 diabetes in Swedish men with a short duration. Taking our present study and recent reports together, we also suggest that increased IGFBP1 DNA methylation and decreased IGFBP-1 serum levels are features of type 2 diabetes.

\section{Methods}

\section{Subjects}

A sample of Swedish men, comprising 242 subjects with normal glucose tolerance (non-diabetic controls) and 164 patients with type 2 diabetes, was studied. They were all participants of SDPP and lived in the municipalities of Värmdö, Upplands-Bro, Tyresö or Sigtuna in Stockholm County [22]. The subjects with normal glucose tolerance were age-matched with type 2 diabetes patients (mean age 58 years). Of the patients, 89 were newly diagnosed and not receiving medication when the clinical data were recorded. The other 75 patients had had diabetes for a mean of 3 years and were being treated with advice on physical exercise and diet control (29.3\%), OADs (53.3\%), insulin (5.3\%) or a combination of these (4.0\%). In SDPP, information on smoking status, physical activity levels and alcohol consumption were recorded for all participants based upon questionnaires [22].

All patients with type 2 diabetes in SDPP were diagnosed according to the World Health Organization (WHO) criteria [23]. FHD was defined as having at least one first-degree relative (parent or sibling) or at least two second-degree relatives (grandparents, uncles or aunts) with diabetes. The clinical characteristics of the subjects are summarized in Table 1. All data shown are means (95\% CI) except fasting insulin where geometric means (95\% CI) are given. $P$ values from Tukey post hoc tests were between type 2 diabetes patients either newly diagnosed or receiving treatment and non-diabetic controls. No differences were found between newly diagnosed patients and patients receiving treatment.

Informed consent has been received from all participants. The study has been approved by the Ethics Committee of Karolinska University Hospital and was performed in accordance with the Declaration of Helsinki II.

\section{DNA extraction and bisulfite treatment}

We analysed human IGFBP1 DNA methylation levels in genomic DNA samples. Genomic DNA was extracted from peripheral blood in all subjects using the Gentra Puregene Blood Kit (Qiagen, Hilden, Germany), which enables purification of high molecular weight DNA (100 kb to $200 \mathrm{~kb}$ ) suitable for archiving. The scalable purification procedure gently removes contaminants and inhibitors and large-volume samples can be purified for genetic and 
Table 1 Clinical characteristics of Swedish men with normal glucose tolerance or type 2 diabetes

\begin{tabular}{|c|c|c|c|}
\hline Characteristic & Non-diabetic subjects & $\begin{array}{l}\text { Patients with newly diagnosed } \\
\text { type } 2 \text { diabetes }\end{array}$ & $\begin{array}{l}\text { Patients with type } 2 \\
\text { diabetes receiving treatment }\end{array}$ \\
\hline $\bar{N}$ & 242 & 89 & 75 \\
\hline$(\mathrm{FHD}-/+)$ & $(178 / 64)$ & $(26 / 63)$ & $(12 / 63)$ \\
\hline Age (years) & $58(57-58)$ & $58(57-59)$ & $59(58-60)$ \\
\hline $\mathrm{BMI}\left(\mathrm{kg} / \mathrm{m}^{2}\right)$ & $26.1(25.9-26.3)$ & $29.3(28.4-30.3)^{* * *}$ & $30.5(29.4-31.5)^{* * *}$ \\
\hline WC $(\mathrm{cm})$ & $93.2(92.4-94.0)$ & $101.8(99.4-104.3)^{* * *}$ & $103.7(101.2-106.2)^{* * *}$ \\
\hline Glucose (mmol/L) & $5.0(4.9-5.1)$ & $7.6(7.1-8.1)^{* * *}$ & $8.3(8.1-9.0)^{* * *}$ \\
\hline Insulin (pmol/L) & $96.7(91.9-101.8)$ & $166.1(150.0-157.8)^{* * *}$ & $160.0(140.0-181.8)^{* * *}$ \\
\hline $\mathrm{SBP}(\mathrm{mmHg})$ & 135 (134-138) & $145(141-149)^{* * *}$ & $145(141-149)^{* * *}$ \\
\hline $\mathrm{DBP}(\mathrm{mmHg})$ & $83(82-84)$ & $88(86-90)^{* * *}$ & $87(85-89)^{*}$ \\
\hline |GF-I (ug/L) & $171(162-180)$ & $162(151-172)$ & 156(147-166) \\
\hline
\end{tabular}

BMI, body mass index; WC, waist circumference; DBP, diastolic blood pressure; FHD, family history of diabetes; IGF, insulin-like growth factor; SBP, systolic blood pressure. $P$ values: ${ }^{*}<0.05,{ }^{*}<0.01$ and ${ }^{* * *}<0.001$.

epigenetic analyses. The stock solution of DNA samples was stored at $-80^{\circ} \mathrm{C}$ until use. For epigenetic analysis, the extracted DNA samples were bisulfite treated using the EpiTect Bisulfite Kit (Qiagen). This kit gives complete conversion of unmethylated cytosine to uracil and subsequent purification in less than 6 hours. This highly sensitive method utilizes an innovative protection against DNA degradation and ensures high conversion rates of over 99\%. DNA extraction and bisulfite treatment were conducted according to the manufacturer's instructions.

\section{IGFBP1 DNA methylation analyses}

There is a CpG island in the promoter and exon 1 of the IGFBP1 gene. We used a PyroMark CpG assay (ENSG00000146678, Qiagen) and PyroMark PCR kit (Qiagen) for the IGFBP1 gene methylation analysis, which included six CpG sites (CGAGCATCTGCCGCCGCGCC GCCGCCACC) at $5^{\prime}$-UTR of the IGFBP1 gene as indicated with the bold letter " $\mathrm{C}$ " and referred to as P1 to P6 ( $\mathrm{P}$ is the position). DNA methylation in mammals is normally found as 5-methyl cytosine followed by guanosine [15]. The PyroMark PCR Master Mix includes HotStarTaq DNA polymerase and the optimized PyroMark reaction buffer containing $3 \mathrm{mM} \mathrm{MgCl}$ and Deoxynucleotidse (dNTPs), 10× CoralLoad concentrate, 5× Q-Solution, 25 $\mathrm{mM} \mathrm{MgCl}$, and RNase-free water. The PCR amplicon length was $177 \mathrm{bp}$ and covers the sequence in human chromosome 7:45928112-45928134 (version 37.56). The methylation levels of these CpG sites were detected using the PyroMark Gold 96 Reagent Kit (Qiagen, Hilden, Germany) and the PyroMark Q96 ID pyrosequencing system (Biotage, Uppsala, Sweden). Pyrosequencing methylation analysis of $\mathrm{CpG}$ sites is a sensitive and accurate protocol $[24,25]$. PyroQ-CpG software (Biotage) was used for methylation data analysis. Unmethylated bisulfite converted and unconverted DNAs (Qiagen) were used to monitor the conversion efficiency of the bisulfite treatment and the accuracy of the methylation analyses.

\section{Assays for serum protein analyses}

Serum samples from all subjects were included in protein analyses. Fasting serum IGFBP-1 and insulin levels were determined using in-house radio-immunoassays (RIAs) with polyclonal antibodies for human IGFBP-1 and insulin, respectively, as previously described [26,27]. The IGFBP-1 protein in serum samples stored at $-20^{\circ} \mathrm{C}$ is stable. The intra- and inter-assay coefficients of variation $(\mathrm{CV})$ values were $3 \%$ and $10 \%$, respectively [13]. Serum IGF-1 levels were measured using an in-house RIA after acid-ethanol extraction and cryoprecipitation. To minimize interference by IGFBPs, des IGF-1 was used as a tracer as previously described [28]. The intra- and inter-assay CV values were $4 \%$ and $11 \%$, respectively.

\section{Statistical analyses}

Data presented in the table and figures are either means with $95 \%$ confidence interval (CI) or geometrical means with $95 \% \mathrm{CI}$ if the data were not normally distributed. Tests for comparison of continuous variables between groups were assessed using an unpaired t-test or one-way ANOVA followed with Tukey's post hoc test. Data in nonnormally distributed traits were transformed to the natural logarithm to give a normal distribution before the statistical analysis was performed. Linear regression analysis was used to examine the relation between variables. A $P$ value less than 0.05 was considered as significant. All data were analysed using the PASW statistic program (SPSS 20.0, Chicago, IL, USA).

\section{Abbreviations}

BMI: Body mass index; FHD: Family history of diabetes; GWAS: Genome-wide association studies; IGF: Insulin-like growth factor; IGFBP-1: Insulin-like growth factor binding protein-1; OAD: Oral anti-diabetic drug; PCR: Polymerase chain reaction; RIA: Radio-immunoassay; SDPP: Stockholm diabetes prevention program. 


\section{Competing interests}

The authors declare that there are no conflicts of interest associated with this paper.

\section{Authors' contributions}

TG, HFG and KB designed the study. LKS and TJE assisted with DNA methylation. TG, HFG and AH researched and analysed the data. CGÖ collected data on subjects. TG, HFG and KB wrote the manuscript. All authors contributed to data interpretation, discussions and commented on the manuscript.

\section{Acknowledgements}

The authors wish to thank all subjects included in the present study for their participation, Ms Elvi Sandberg for laboratory assistance and Drs Mohammed Seed Ahmed and Lars Kärvestedt for valuable discussions. This work was supported by the Family Erling-Persson Foundation, the Swedish Diabetes Association and funds from the Karolinska Institute.

\section{Author details}

'Rolf Luft Research Center for Diabetes and Endocrinology, Department of Molecular Medicine and Surgery, Karolinska Institute, Department of Endocrinology, Karolinska University Hospital, Stockholm SE-17176, Sweden. ${ }^{2}$ Center for Molecular Medicine, Department of Clinical Neuroscience, Karolinska Institute, Karolinska University Hospital, Stockholm, Sweden.

Received: 6 August 2013 Accepted: 30 October 2013

Published: 19 November 2013

\section{References}

1. Billings $L K$, Florez JC: The genetics of type 2 diabetes: what have we learned from GWAS? Ann N Y Acad Sci (2010), 1212:59-77.

2. Ahlqvist E, Ahluwalia TS, Groop L: Genetics of type 2 diabetes. Clin Chem (2011), 57(2):241-254.

3. Imamura M, Maeda S: Genetics of type 2 diabetes: the GWAS era and future perspectives. Endocr J (2011), 58(9):723-739.

4. Ling C, Groop L: Epigenetics: a molecular link between environmental factors and type 2 diabetes. Diabetes (2009), 58(12):2718-2725.

5. Drong AW, Lindgren CM, McCarthy MI: The genetic and epigenetic basis of type 2 diabetes and obesity. Clin Pharmacol Ther (2012), 92(6):707-715

6. Kirchner $\mathrm{H}$, Osler ME, Krook A, Zierath JR: Epigenetic flexibility in metabolic regulation: disease cause and prevention? Trends Cell Biol (2013), 23(5):203-209.

7. Suikkari AM, Koivisto VA, Koistinen R, Seppälä M, Yki-ärvinen H: Dose-response characteristics for suppression of low molecular weight plasma insulin-like growth factor-binding protein by insulin. J Clin Endocrinol Metab (1989), 68(1):135-140.

8. Brismar K, Fernqvist-Forbes E, Wahren J, Hall K: Effect of insulin on the hepatic production of insulin-like growth factor-binding protein-1 (IGFBP-1), IGFBP-3, and IGF-I in insulin-dependent diabetes. J Clin Endocrinol Metab (1994), 79(3):872-878.

9. Petersson U, Ostgren CJ, Brudin L, Brismar K, Nilsson PM: Low levels of insulin-like growth-factor-binding protein-1 (IGFBP-1) are prospectively associated with the incidence of type 2 diabetes and impaired glucose tolerance (IGT): the Söderåkra cardiovascular risk factor study. Diabetes Metab (2009), 35(3):198-205.

10. Rajpathak SN, Gunter MJ, Wylie-Rosett J, Ho GY, Kaplan RC, Muzumdar R, Rohan TE, Strickler HD: The role of insulin-like growth factor-I and its binding proteins in glucose homeostasis and type 2 diabetes. Diabetes Metab Res Rev (2009), 25(1):3-12.

11. Gokulakrishnan K, Velmurugan K, Ganesan S, Mohan V: Circulating levels of insulin-like growth factor binding protein-1 in relation to insulin resistance, type 2 diabetes mellitus, and metabolic syndrome (Chennai urban rural epidemiology study 118). Metabolism (2012), 61(1):43-46.

12. Hong Y, Brismar K, Hall K, Pedersen NL, de Faire U: Associations between insulin-like growth factor-I (IGF-I), IGF-binding protein-1, insulin and other metabolic measures after controlling for genetic influences: results from middle-aged and elderly monozygotic twins. J Endocrinol (1997), 153(2):251-257.

13. Lewitt MS, Hilding A, Ostenson CG, Efendic S, Brismar K, Hall K: Insulin-like growth factor-binding protein-1 in the prediction and development of type 2 diabetes in middle-aged Swedish men. Diabetologia (2008), 51(7):1135-1145
14. Lewitt MS, Hilding A, Brismar K, Efendic S, Ostenson CG, Hall K: IGF-binding protein 1 and abdominal obesity in the development of type 2 diabetes in women. Eur J Endocrinol (2010), 163(2):233-242.

15. Lister R, Pelizzola M, Dowen RH, Hawkins RD, Hon G, Tonti-Filippini J, Nery JR, Lee L, Ye Z, Ngo QM, Edsall L, Antosiewicz-Bourget J, Stewart R, Ruotti V, Millar AH, Thomson JA, Ren B, Ecker JR: Human DNA methylomes at base resolution show widespread epigenomic differences. Nature (2009), 462(7271):315-322.

16. Murrell A, Rakyan VK, Beck S: From genome to epigenome. Hum Mol Genet (2005), S1:R3-R10

17. Schumacher A, Petronis A: Epigenetics of complex diseases: from general theory to laboratory experiments. Curr Top Microbiol Immunol (2006), 310:81-115.

18. Barrès R, Yan J, Egan B, Treebak JT, Rasmussen M, Fritz T, Caidahl K, Krook A, O'Gorman DJ, Zierath JR: Acute exercise remodels promoter methylation in human skeletal muscle. Cell Metab (2012), 15(3):405-411.

19. Yin $\mathrm{H}$, Blanchard KL: DNA methylation represses the expression of the human erythropoietin gene by two different mechanisms. Blood (2000), 95(1):111-119.

20. Rehman JU, Brismar K, Holmbäck U, Akerstedt T, Axelsson J: Sleeping during the day: effects on the 24-h patterns of IGF-binding protein 1, insulin, glucose, cortisol, and growth hormone. Eur J Endocrinol (2010), 163(3):383-390.

21. Humphriss DB, Stewart MW, Berrish TS, Barriocanal LA, Trajano LR, Ashworth LA, Brown MD, Miller M, Avery PJ, Alberti KG, Walker M: Multiple metabolic abnormalities in normal glucose tolerant relatives of NIDDM families. Diabetologia (1997), 40(10):1185-1190.

22. Eriksson AK, Ekbom A, Granath F, Hilding A, Efendic S, Ostenson CG: Psychological distress and risk of pre-diabetes and type 2 diabetes in a prospective study of Swedish middle-aged men and women. Diabet Med (2008), 25(7):834-842.

23. Alberti KG, Zimmet PZ: Definition, diagnosis and classification of diabetes mellitus and its complications: part 1: diagnosis and classification of diabetes mellitus provisional report of a WHO consultation. Diabet Med (1998), 15(7):539-553.

24. Tost J, Dunker J, Gut IG: Analysis and quantification of multiple methylation variable positions in CpG islands by pyrosequencing. BioTechniques (2003), 35(1):152-156.

25. Colella S, Shen L, Baggerly KA, Issa JP, Krahe R: Sensitive and quantitative universal pyrosequencing methylation analysis of $\mathrm{CpG}$ sites. BioTechniques (2003), 35(1):146-150.

26. Póvoa G, Roovete A, Hall K: Cross-reaction of serum somatomedin-binding protein in a radioimmunoassay developed for somatomedin-binding protein isolated from human amniotic fluid. Acta Endocrinol (Copenh) (1984), 107(4):563-570

27. Grill V, Pigon J, Hartling SG, Binder C, Efendic S: Effects of dexamethasone on glucose-induced insulin and proinsulin release in low and high insulin responders. Metabolism (1990), 39(3):251-258.

28. Bang P, Eriksson U, Sara V, Wivall IL, Hall K: Comparison of acid ethanol extraction and acid gel filtration prior to IGF-I and IGF-II radioimmunoassays: improvement of determinations in acid ethanol extracts by the use of truncated IGF-I as radioligand. Acta Endocrinol (Copenh) (1991), 124(6):620-629.

doi:10.1186/1868-7083-5-21

Cite this article as: Gu et al: Increased DNA methylation levels of the insulin-like growth factor binding protein 1 gene are associated with type 2 diabetes in Swedish men. Clinical Epigenetics 2013 5:21. 